Научная статья

УДК 373

DOI: 10.18101/2307-3330-2021-2-54-60

\title{
СОЦИАЛИЗАЦИЯ СОВРЕМЕННЫХ ДОШКОЛЬНИКОВ В ГРУППЕ СВЕРСТНИКОВ: РЕАЛИИ И ПЕРСПЕКТИВЫ
}

\author{
(C) Гребенникова Ольга Владимировна \\ кандидат психологических наук, доцент, \\ Психологический институт Российской академии образования \\ 125009, Россия, Москва, ул. Моховая, 9, стр. 4 \\ grebennikova577@mail.ru
}

\begin{abstract}
Аннотация. Статья посвящена актуальной проблеме социализации современных дошкольников в группе сверстников, так как общение между ними является важнейшим аспектом, без которого невозможно дальнейшее становление личности ребенка. Результаты эмпирического исследования $(\mathrm{n}=110)$ позволили выделить три типа социализации современных дошкольников: позитивную, диффузную и негативную. Современные старшие дошкольники, имеющие позитивную социализацию в группе сверстников, характеризуются вхождением в благоприятную статусную категорию «звезды», высоким уровнем межличностного общения и межличностных отношений (активностью в общении и широтой круга общения, преобладанием игрового мотива общения, положительным отношением к сверстникам, наличием положительного эмоционального фона, наличием просоциальных действий, положительным отношением к лидерству, автономии от сверстника), выбора позитивной стратегии в отношении сверстника (желание играть, общаться, помощь), а также наличием коммуникативных ценностей. Большинство современных дошкольников 5-6 лет, имеющих диффузную и негативную социализацию в группе сверстников, нуждаются в своевременной и профессиональной помощи со стороны педагогов, психологов и родителей.

Ключевые слова: социализация, старшие дошкольники, общение, взаимодействие, группа сверстников, сотрудничество, социальные навыки.
\end{abstract}

\section{Для цитирования}

Гребенникова О. В. Социализация современных дошкольников в группе сверстников: реалии и перспективы // Вестник Бурятского государственного университета. Образование. Личность. Общество. 2021. № 2. С. 54-60.

Социализация дошкольника - это сложный путь, в котором нет готовых решений на все вопросы и в котором ребенку приходится решать множество задач и постоянно сталкиваться с интересами других людей, соотносить с ними собственные желания. Ребенок стремится быть включенным в общество, он осваивает новые роли и принимает либо отвергает новые правила. Важнейшим аспектом здесь является общение между сверстниками, без которого невозможно становление личности и восприятие картины мира.

На этапе дошкольного детства в процессе социализации у ребенка появляется новое направление общения - горизонтальное, в котором равноправным партнером становится сверстник. Начинает складываться доминирование 
О. В. Гребенникова. Социализация современных дошкольников в группе сверстников: реалии и перспективы

позиции сверстника по отношению к позиции взрослого, отношения со сверстниками становятся все более разноплановыми и функциональными.

Вопросы социализации дошкольников, особенностей их взаимодействия в группе сверстников были рассмотрены в работах таких авторов, как Т. И. Бабаева - социально-эмоциональное развитие дошкольников (2001); Н. Ф. Голованова - социализация и воспитание ребенка (2004); М. И. Лисина (1986); Н. А. Лялина - развитие взаимопонимания в общении старших дошкольников со сверстниками (2007); Е. О. Смирнова, Е. В. Калягина - отношение популярных и непопулярных дошкольников со сверстниками (1998); Т. А. Репина, Р. Б. Стеркина - общение дошкольников в совместной деятельности в группе детского сада, межличностные отношения дошкольников (1990); Л. С. Римашевская - сотрудничество старших дошкольников (2007) и др. [2].

Группа сверстников на основе детского дошкольного учреждения обладает важнейшим свойством для развития и социализации личности в этом возрасте. Влияние на эмоциональное самочувствие детей и общее отношение к детскому саду теперь находится в зависимости от характера отношений ребенка со сверстниками. Для ребенка с четырехлетнего возраста сверстник становится более предпочитаемым партнером по общению. Так называемые горизонтальные отношения, отношения между сверстниками, отличаются равноправием, здесь приобретаются основные социальные навыки. Общение со сверстниками предполагает контакты равного статуса, учитывающие точку зрения друг друга.

В процессе социализации ребенок не прямо подражает взрослым, точно запечатлевая их слова, действия, поступки, а организует собственное поведение по тому социальному образцу, который освоил во взаимодействии со взрослыми.

Для понимания психологической природы социализации ребенка очень важны попытки Л. С. Выготского найти тот «первокирпичик», ту единицу самой «социальной ситуации развития», когда сталкиваются, вступают во взаимодействие влияние среды и внутренние отношения ребенка. Такой «единицей» он считает «переживание». Именно переживание ребенка является «индикатором» его социализации, в нем проявляется своеобразное соотношение внешней и внутренней сил социального развития, то, как он понимает происходящие события, явления, поступки людей и как к ним относится, насколько принимает или отторгает.

В концепции М. И. Лисиной общение выступает как особая коммуникативная деятельность, направленная на формирование взаимоотношений. Как утверждает Е. О. Смирнова, если общение осуществляется в тех или иных формах взаимодействия с помощью некоторых внешних средств, то отношение - это аспект внутренней, душевной жизни, это характеристика сознания, которая не предполагает фиксированных средств выражения. Таким образом, отношения можно рассматривать как внутреннюю психологическую основу общения и взаимодействия людей [4].

По мнению Г. А. Цукерман, общение и совместная деятельность со сверстниками является одним из основных факторов психического развития ребенка [2]. Несмотря на их значимость, все дети дошкольного возраста раз- 
личаются границами взаимодействия со сверстниками. Такое утверждение подтверждается с помощью феномена популярности. Этот феномен является предметом многочисленных исследований, как в зарубежной, так и в отечественной психологии. «Установлено, что границы взаимодействия детей со сверстниками у популярных дошкольников шире, чем у непопулярных» $[1$, с. 50].

По утверждению А. Э. Симановского, «более популярные в социальной среде дети-дошкольники обладают рядом социальных навыков: владеют разнообразными социальными навыками; постепенно подключаются к групповым занятиям, делая уместные замечания, делясь информацией, и только потом переходят к активным действиям; чувствительны к потребностям и действиям других; не навязывают свою волю другим детям; соглашаются играть рядом с другими детьми; умеют поддержать дружеские отношения; при необходимости приходят на помощь; способны поддержать разговор; делятся интересной информацией; откликаются на предложения других детей; умеют разрешать конфликты; в конфликтных ситуациях не склонны к агрессии или применению физической силы» [3, с. 197-199].

Как утверждает Г. Р. Хузеева, «границы взаимодействия детей со сверстниками у популярных дошкольников шире, чем у непопулярных. На степень популярности в группе сверстников могут влиять высокий уровень регуляции поведения, высокий уровень развития игры, способность понимать намерения, чувства, желания другого человека». Причиной популярности детей-дошкольников служат их игровые, коммуникативные, нравственные качества $[1$, с. 51$]$.

Е. О. Смирнова считает, что главным качеством, определяющим популярность дошкольника, является отношение ребенка к сверстнику, а именно чувствительность и наличие интереса к сверстнику, наличие просоциальных действий, сопереживания другому ребенку. Низкий уровень популярности связывают с низким уровнем регуляции поведения, низким уровне игры, высоким уровнем тревожности, высоким уровнем агрессивного поведения [1].

В общении со сверстниками у ребенка закладываются не только основы морали и нравственного поведения, но и возникают избирательные привязанности между детьми. По данным Р. А. Смирновой, в основе дружеских отношений детей лежит удовлетворение потребности в доброжелательном внимании сверстников; оно обеспечивает познание детьми себя в своих лучших качествах. На втором по значению месте для формирования дружеских связей стоит удовлетворение потребности детей в игровом сотрудничестве, а стремление к общности мнений и взглядов занимает лишь скромное третье место [2].

Проанализировав психологическое содержание процесса социализации дошкольника, необходимо выделить некоторые критерии уровней различных компетенций дошкольника:

- уровень социальной компетентности, которая включает знание, принятие и готовность реализовывать основные социальные нормы; 
О. В. Гребенникова. Социализация современных дошкольников в группе сверстников: реалии и перспективы

- уровень эмоциональной компетентности, характеризующейся умением понимать и выражать свои эмоциональные состояния и состояния партнеров по общению;

- уровень когнитивной компетентности, при котором ребенок способен распознавать различные виды социального взаимодействия, а также различные причины конфликтов;

- уровень личностной компетентности, включающей способность к саморегуляции, рефлексивному контролю ситуаций взаимодействия, осознание и переживание своей индивидуальности.

В современных условиях развития общества, когда информационные технологии активно внедряются в жизнь ребенка, а приоритетным направлением становится интеллектуальная деятельность, игровая деятельность меняет свое содержание и назначение, отсутствие постоянного детского сообщества и маркетизация детства вносят свои изменения и в процесс межличностного общения дошкольника с другими детьми, что обусловливает проведение новых эмпирических исследований.

Нами изучены особенности социализации детей старшего дошкольного возраста в группе сверстников. Выборка составила 110 человек в возрасте 5-6 лет, посещающих дошкольные учреждения г. Москвы и Московской области. Подобран следующий диагностический инструментарий: метод социометрии (определяет социометрический статус подростка в группе); схема наблюдения «Особенности общения детей дошкольного возраста со сверстниками» (модификация и критерии анализа: Г. Р. Хузеева) (направлен на выявление особенностей общения детей старшего дошкольного возраста); методика «Особенности межличностных отношений (OMO)» (направлена на определение межличностного общения ребенка со взрослыми и сверстниками, отношение к лидерству, субъективное ощущение включенности ребенка в группу сверстников, эмоциональное отношение к сверстникам и взрослым); методика «Шапка-невидимка» (направлена на изучение скрытых социальных установок, особенностей ситуативного общения со взрослыми и сверстниками, особенностей нормативного поведения ребенка и содержания неудовлетворенных потребностей); методика «Три желания» (направлена на изучение ценностных ориентаций личности, особенностей личности ребенка, а также социальных и моральных установок личности).

Обобщив полученные результаты эмпирического исследования, мы выделили следующие виды социализации старших дошкольников в группе сверстников.

Выявлено, что $20 \%$ старших дошкольников имеют позитивную социализацию в группе сверстников, которая характеризуется вхождением детей в благоприятную статусную категорию «звезды», высоким уровнем межличностного общения и межличностных отношений (активностью в общении и широтой круга общения, преобладанием игрового мотива общения, положительным отношением к сверстникам, наличием положительного эмоционального фона, наличием просоциальных действий, положительным отношением к лидерству, автономии от сверстника), выбора позитивной стратегии в отно- 
шении сверстника (желание играть, общаться, помочь), а также наличием коммуникативных ценностей.

Диффузная социализация в группе сверстников присутствует у 50\% старших дошкольников и характеризуется вхождением в статусную категорию «предпочитаемые» и «принятые», средним уровнем межличностного общения и межличностных отношений (наличием игрового, делового и познавательного мотивов общения, широким кругом общения, пассивной позиции в общении, положительным и амбивалентным отношением к сверстникам, наличием положительного эмоционального фона, отсутствием просоциальных действий, положительным отношением к лидерству, подчинение сверстнику). Кроме того, выбором как позитивной (играть, общаться), так и негативной стратегии в отношении сверстника (стремление напугать, агрессия), наличием познавательных и материальных ценностей.

Негативную социализацию в группе сверстников имеют $30 \%$ старших дошкольников. И она характеризуется вхождением детей в неблагоприятную статусную категорию «принятые» и «непринятые», низким уровнем межличностного общения и межличностных отношений (пассивностью в общении и узостью круга общения, выбора личностного мотива общения, отрицательным отношением к сверстникам, наличием негативного эмоционального фона, отсутствием просоциальных действий, отрицательным отношением к лидерству, подчинение сверстнику) и выбора негативной стратегии в отношении сверстника (агрессия, стремление напугать), а также наличием материальных ценностей.

Проведенное нами эмпирическое исследование позволяет сделать следующие выводы:

1. Социометрический статус современных старших дошкольников обеспечивает не только популярность в группе сверстников, но и определяет уровень межличностного общения и межличностных отношений, выбор стратегии взаимодействия и ведущие ценности ребенка. Большинство старших дошкольников имеют социометрический статус: «предпочитаемые» и «принятые», в меньшинстве остаются «звезды» и «непринятые».

2. Наблюдается противоречивость в содержании межличностного общения и межличностных отношений старших дошкольников. У большинства детей ведущим выступает игровой мотив, который не связан с ярко выраженной потребностью в игре со сверстниками, на первый план выходят игрушки и дидактические игры, не требующие ролевого репертуара. А сюжетно-ролевая игра чаще задается взрослым. Большинство старших дошкольников демонстрируют пассивную позицию в общении, подчинение сверстнику при желании широкого круга общения и положительного отношения к лидерству. Практически большая часть детей проявляют положительное отношение к сверстникам и в то же время выбирают негативные стратегии взаимодействия. Возможно, это связано с недостаточным уровнем развития коммуникативных навыков детей и вытеснением ведущей игровой деятельности в дошкольном образовании занятиями учебного характера, включением детей в семье в раннее обучающее пространство. 
О. В. Гребенникова. Социализация современных дошкольников в группе сверстников: реалии и перспективы

3. Современные старшие дошкольники, имеющие позитивную социализацию в группе сверстников, характеризуются вхождением в благоприятную статусную категорию «звезды», высоким уровнем межличностного общения и межличностных отношений (активностью в общении и широтой круга общения, преобладанием игрового мотива общения, положительным отношением к сверстникам, наличием положительного эмоционального фона, наличием просоциальных действий, положительного отношения к лидерству, автономии о сверстника), выбором позитивной стратегии в отношении сверстника (желание играть, общаться, помощь), а также наличием коммуникативных ценностей.

4. Большинство современных дошкольников 5-6 лет, имеющих диффузную и негативную социализацию в группе сверстников, нуждаются в своевременной и профессиональной помощи со стороны педагогов, психологов и родителей. Возможно, эта тенденция связана с усиленной включенностью современных дошкольников в цифровую социализацию, использованием гаджетов и снижением интереса к реальной группе сверстников.

\section{Литература}

1. Авдулова Т. П., Хузеева Г. Р. Психологическое содержание процесса социализации дошкольников // Психолог в детском саду. 2008. № 4. С. 45-53. Текст: непосредственный.

2. Гребенникова О. В. Психолого-педагогические условия развития произвольного поведения дошкольников // Психологические исследования. 2009. № 1(3). URL: http://psystudy.ru/index.php/num/2009n1-3/46-rebennikova3.html?fontstyle=f-smaller (дата обращения: 30.09.2021). Текст: электронный.

3. Симановский А. Э. Педагогическая психология: учебное пособие. Москва: Издво Моск. психол.-социал. ин-та; Воронеж: МОДЭК, 2008. 304 с. Текст: непосредственный.

4. Смирнова Е. О., Холмогорова В. М. Межличностные отношения дошкольников: диагностика, проблемы, коррекция. Москва: ВЛАДОС, 2005. 158 с. Текст: непосредственный.

Статья поступила в редакиию 05.06.2021; одобрена после рещчензирования 05.07.2021; принята к публикаџии 29.11.2021.

\section{SOCIALIZATION OF MODERN PRESCHOOLERS IN A PEER GROUP: REALITIES AND PROSPECTS}

Olga V. Grebennikova

Cand. Sci. (Psychology), A/Prof., Psychological Institute of the Russian Academy of Education 9/4 Mokhovaya St., Moscow 125009, Russia grebennikova577@mail.ru

Abstract. The article is devoted to the issues of socialization of modern preschoolers in a peer group. Peer-to-peer communication is one of the most important aspects of personality development. The results of the empirical study $(n=110)$ allowed us to distinguish three types of socialization of modern preschoolers: positive, diffuse and 
negative. Modern over-fives with positive socialization in a peer group enter a favorable status of «stars», have a high level of interpersonal communication and interpersonal relationships (activity in communication, wide circle of contacts, predominance of play-based communication, positive attitude towards peers, positive emotional background, prosocial behavior, positive regard of leadership, individual autonomy), choose positive strategy in relationships with peers (desire of playing, communicating, helping), and possess communicative values. The majority of modern over-fives with diffuse and negative socialization in a peer group need timely professional help from teachers, psychologists and parents.

Keywords: socialization, over-fives, communication, interaction, peer group, collaboration, social skills.

\section{For citation}

Grebennikova O. V. Socialization of Modern Preschoolers in a Peer Group: Realities and Prospects. Education. Person. Society. 2021; 2: 54-60 (In Russ.).

The article was submitted 05.06.2021; approved after reviewing 05.07.2021; accepted for publication 29.11.2021. 